\title{
Wyrok Sądu Metropolitalnego w Katowicach (c. Sobański) z 26.11.2004 z tytułu bojaźni szacunkowej po stronie powoda
}

Ius Matrimoniale 10 (16), 235-238

2005

Artykuł został opracowany do udostępnienia w internecie przez Muzeum Historii Polski w ramach prac podejmowanych na rzecz zapewnienia otwartego, powszechnego i trwałego dostępu do polskiego dorobku naukowego i kulturalnego. Artykuł jest umieszczony w kolekcji cyfrowej bazhum.muzhp.pl, gromadzącej zawartość polskich czasopism humanistycznych i społecznych.

Tekst jest udostępniony do wykorzystania w ramach dozwolonego użytku. 


\section{Wyrok Sadu Metropolitalnego w Katowicach (c. Sobański) z 26.11.2004 z tytułu bojaźni szacunkowej po stronie powoda}

\section{Przebieg sprawy:}

RP oraz WG zawarli małżeństwo 23.10.1971 w kościele św. Marcina w P. Ważność tego malżeństwa zaskarżył RP 28.6.2000 w Sądzie Duchownym w W. z tytułów przymusu i bojaźni po stronie powoda, bojaźni szacunkowej po stronie powoda oraz symulacji po stronie powoda i pozwanej. Sąd rozpatrzyl sprawę z powyższych czterech tytulów. Dnia 6.4.2002 Sąd orzekł, że nie udowodniono nieważności małżeństwa z żadnego $\mathrm{z}$ rozpatrywanych tytułów. Wskutek apelacji powoda sprawa znalazła się w II instancji, tj. w Sądzie Duchownym w P. Sąd ten rozpatrywał sprawę tylko z tytułu bojaźni szacunkowej i orzekł 26.4.2003, że z tego właśnie tytułu udowodniono nieważność małżeństwa. Na prośbę powoda Najwyższy Trybunal Sygnatury Apostolskiej reskryptem z 3.2.2004 wyznaczył Sąd Metropolitalny w Katowicach do rozpatrzenia sprawy w trzeciej instancji. Dekretem z 15.4.2004 ustalono skład osobowy Sądu. Strony nie przedłożyly nowych wniosków dowodowych, przeto dekretem z 26.7.2003 zamknięto postępowanie dowodowe. Tak więc opierając się na materiale dowodowym nagromadzonym w poprzednich instancjach Sąd przystępuje do udzielenia odpowiedzi na pytanie procesowe, czyli do orzeczenia, czy udowodniono nieważność małżeństwa z tytułu bojaźni szacunkowej po stronie powoda.

\section{Prawny stan sprawy:}

Trybunał I instancji rozpatrywał sprawę - jak wspomniano wyżej z trzech tytułów i orzekł, że nie udowodniono nieważności z żadnego z nich. Powód w piśmie apelacyjnym polemizuje z ustaleniami Trybunału dotyczącymi wywartego nań przymusu. Trybunał II instancji ustalil pytanie procesowe: czy malżeństwo stron jest nieważne $z$ tytułu bojaźni szacunkowej po stronie powoda i z tego tytułu orzekł nieważność 
małżeństwa, innych tytułów nieważności Trybunał II instancji nie rozpatrywał (nie można przeto twierdzić, że odnośnie do nich zatwierdził wyrok Trybunału I instancji - p. II, 29). Sąd Metropolitalny został upoważniony do rozpatrywania sprawy z tytułu, co do którego zapadły niezgodne wyroki, tj. z tytułu bojaźni szacunkowej po stronie powoda. Sąd zwraca uwagę na ten fakt, gdyż powód po otrzymaniu uwag obrońcy węzła małżeńskiego, w piśmie z 28.7.2004 przywołał także obustronną symulację małżeńską.

\section{Stan faktyczny:}

1. Skoro tytułem nieważności jest bojaźń szacunkowa po stronie powoda, trzeba wziąć pod uwagę przede wszystkim jego zeznania. Powód zeznając w I instancji podał, że strony byly „znajomymi z paczki”, znajomość zostala przerwana wskutek jego „pójścia do wojska”, ale gdy jeden jedyny raz przyjechal na przepustkę, pozwana zaszła w ciążę. Nie widział w niej kandydatki na żonę, ale jak zaszła w ciążę, ,to już była inna sprawa". Po trzech miesiącach musiał podjąć rozmowę o tym z rodzicami, a „wtedy po przymusach rodziców” musial ,podjąć decyzję o zawarciu małżeństwa", choć nie był na to przygotowany i spadło to nań ,jak grom z jasnego nieba”. Twierdzenie, że rozmowę z rodzicami podjąl w trzy miesiące po dowiedzeniu się o ciąży, kłóci się z następnym zdaniem, kiedy zeznaje: „ślub zawarliśmy chyba po trzech miesiącach od chwili zajścia w ciążę przez pozwaną". Powód nie podaje na czym polegały „te przymusy”, po których musiał podjąć decyzję na małżeństwo. Mówi, że nie był przekonany do małżeństwa, małżeństwo „stało się, bo była ta ciąża i namowy rodziców”, ciąża go „przygniotła”, kierował się tylko „problemem ciąży pozwanej i namowami rodziców", gdyby nie ciąża, to najprawdopodobniej małżeństwo nie zostałoby zawarte. Był zmuszany, ale trudno mówić o groźbach, jednak byl tak wychowany, że „nawet mając dwadzieścia lat” we wszystkim słuchał rodziców. Uważa, że gdyby nie zdecydował się na małżeństwo i przeciwstawiłby się rodzicom, to „delikatnie mówiąc wygoniliby” go z domu, zwłaszcza że po ślubie kazali mu „iść mieszkać do teściowej". Powód był im zawsze posłuszny, nigdy się nie sprzeciwiał, a "ten problem przymusu byl w gronie rodzinnym załatwiany".

2. Pozwana przyznaje, że rodzice powoda wymagali od niego bezwzględnego posłuszeństwa, ale nic jej nie wiadomo o przymusie czy też 
ewentualnych konsekwencjach, jakie mogłyby wyniknąć z przeciwstawienia się powoda rodzicom. Małżeństwo stron nigdy nie było związkiem idealnym, ,a kiedy minęlo miłosne rozczarowanie (!), zaczęło się rozpadać zupełnie”. Powód zatruwał jej życie „chorobliwą zazdrością, awanturami, biciem i katowaniem dziecka".

3. W relacji matki powoda sprawa wygląda następująco: „Nie wiem, jak oni podchodzili do decyzji na małżeństwo. A konkretnie ja powiedziałam mu, jak wyszła sprawa ciąży, że skoro tak jest, to nie ma o czym mówić i ma być ślub. Gdybym ją znała, to może postąpiłabym inaczej. Bałam się wstydu, złej opinii... Ja syna zmusiłam do małżeństwa, bo bylo mi wstyd. Z tego nawet pochorowaliśmy się. Powiedzialam mu, że nie ma o czym mówić, tylko ma się żenić, jest dziecko i musi mieć ojca. On płakał, ale nie wiem, dlaczego. Ale nic nie mówił, że nie chce się żenić. Myśmy zawsze wymagali od niego posłuszeństwa i on był uległy nam, musiał słuchać, bo ojciec mial ostrą rękę. Rygor musial być. Gdyby się sprzeciwial, to nie wiem, co by bylo... Nie wiem, czy powód skarżył się, że jest do ślubu zmuszony".

4. Ks. G. nie wie, czy powód ,tylko pod wplywem nalegania rodziców zgodził się na ślub, czy bylo u niego coś inne", nie wie, czy powód skarżył się na przymus. Świadek ostrzegał powoda, by zastanowił się, „,na kogo idzie", świadek nie podaje, jak powód reagował na owe ostrzeżenia. Informacje o małżeństwie stron świadek ma od matki powoda, która po ślubie opowiadała mu o życiu małżeńskim syna.

Świadek T. zeznała: „Propozycja zawarcia małżeństwa wypłynęla ze strony matki P., ponieważ w drodze było dziecko, które musiało mieć ojca. Druga strona przyjęła to $z$ ulgą... Jak pamiętam, młodych zmuszali rodzice do zawarcia małżeństwa". Świadek nie podaje, skąd to wie, nie wyjaśnia, na czym polegał ów przymus, nie wie, jak reagował powód, nie wie nic o znajomości przedślubnej stron.

5. Powód w piśmie apelacyjnym przytacza fragmenty powyższych zeznań wyrażając zdziwienie, dlaczego Trybunał I instancji uznał je za niewystarczające. W piśmie z 2.8.2002 twierdzi, że gdy przedstawił sprawę rodzicom i powiedział, że nie chce tego dziecka, ojciec ,porządnie rozprawił się" $\mathrm{z}$ nim i to tak, że „matka robiła okłady”. Pisze też, że jego „dylemat” nie skończył się „na karze cielesnej i lekcji moralności”, bo zmuszano go do małżeństwa "grożąc skazaniem na cierpienie za wstyd przyniesiony rodzinie, z jednoczesnym wydziedziczeniem". Gdy przyjeżdżał na przepustki, miały miejsce wymówki, szturchańce, psychiczne dręczenie, okazywanie niezadowolenia, nazywanie 
go czarną owcą i ,inne poczynania, łącznie z wyrzuceniem z domu”. Kłóci się to z jego zeznaniami, kiedy przyznał wyraźnie „,trudno mówić o groźbach”, a o jakimś ,poważnym rozprawieniu się” w ogóle nie wspomniał, mimo wyraźnego odnośnego pytania.

6. Jak już zaznaczono wyżej, w sprawach prowadzonych z tytułu bojaźni szacunkowej węzłowe znaczenie mają zeznania i wypowiedzi osoby zainteresowanej, w tym przypadku powoda. I właśnie wypowiedzi powoda sprawiają Sądowi największą trudność. Twierdzenia zawarte w piśmie apelacyjnym są sprzeczne z zeznaniami złożonymi w I instancji. To zaś stawia pod znakiem zapytania wiarygodność powoda: sprzeciwiał się czy bał się sprzeciwić, były groźby czy nie było gróźb (bo wobec jego posłuszeństwa nie były potrzebne). Matka powoda zeznaje, że nie wie, co by było, gdyby się sprzeciwił. A skoro nie sprzeciwial się, to skąd owo rozprawianie się z nim lącznie z karami cielesnymi?

Sprawę rozpatruje się z tytułu bojaźni szacunkowej, dlatego w świetle przedmiotu sprawy nie jest ważne, czy powodowi grożono (wyrzuceniem $z$ domu, wydziedziczeniem) lub też czy byl bity i to tak, że matka musiała robić mu okłady. Trudność Sądu polega na sprzecznościach w relacjach powoda: jeżeli przesadza w pismach, skąd pewność, że mówi prawdę w zeznaniach. Co więcej, odnośnie do gróźb wypowiedzi powoda wykluczają się. Powód sam podważyl swą wiarygodność.

Wypowiedzi samego powoda rodzą wątpliwości, jakim dał już wyraz Trybunał I instancji pisząc w wyroku, że ,nie wiadomo, gdzie jest prawda w twierdzeniach powoda". Jego sprzeczne wypowiedzi nie pozwalają Sądowi osiągnąć moralnej pewności, jakoby powód zawierał małżeństwo pod wplywem bojaźni szacunkowej.

Tak więc sąd odpowiada przecząco na pytanie procesowe i stwierdza, że nie udowodniono, by powód zawierał małżeństwo pod wplywem bojaźni szacunkowej. Tym samym Sąd uchyla wyrok Trybunału II instancji. 